\title{
Visa clampdown hits home at US universities
}

Kendall Powell, Washington

Tighter immigration rules are causing a broad increase in visa delays and refusals for students and postdoctoral fellows seeking entry to the United States, two surveys show. And the problems are set to get worse in the new year, university officials say, when a scheme for tracking the students' movements is due to come into force.

"There is an intrinsic tension between advancing scientific knowledge and national security," says Irving Lerch, director of international affairs at the American Physical Society (APS). "Right now, the argument has come down on the side of security, but in the long run that can be deleterious to our research system, economy and security development."

Although official figures indicate that there was no drop in overall international student enrolment in the United States in the immediate wake of the terrorist attacks on 11 September 2001, the two surveys, conducted separately by the Association of American Universities (AAU) and the APS, indicate a clear effect on those arriving for the 2002-03 academic year.

The number of visiting researchers on 'J visas', for exchange visitors, dropped by $11 \%$ on average at 20 major US universities, the AAU finds. And $20 \%$ of international physics students were denied a visa after being accepted by the 80 departments questioned by the APS.

The surveys indicate that students and postdocs from China, Russia, India, Pakistan and the Middle East were affected most, as immigration officials made use of existing powers to deny visas, for example, if they have reason to suspect that a visa applicant intends to stay in the country permanently.

As a result, researchers say, projects have been postponed, teaching-assistant positions have gone unfilled, some students have gone elsewhere, and scholars have missed scientific conferences. The effect on US universities has been substantial: in 2001, foreign students gained almost half of all US engineering and physical-sciences doctorates and a quarter of those awarded in the life sciences.

But the biggest worry for universities is a looming deadline for the introduction by the Immigration and Naturalization Service of the computerized Student and Exchange Visitor Information System (SEVIS). The system, which has been in development since a stu-

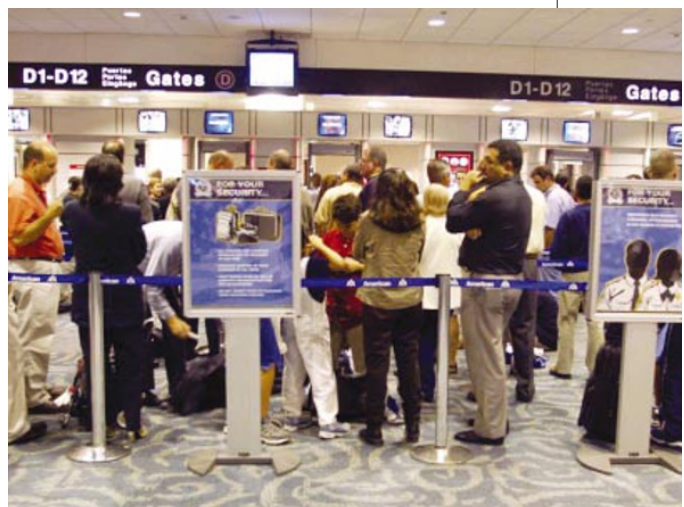

Customary wait: heightened security is hampering foreign students' entry to the United States.

dent was suspected of involvement in the 1993 World Trade Center bombing, aims to track the whereabouts of several hundred thousand holders of F (student), J and M (vocational) visas. It will eventually connect educational institutes, consular offices and ports.

Terry Hartle of the American Council on Education, which represents education interests in Washington, says that implementing this system is a "moonshot" for the immigration service, and claims that good progress has been made on it. But some observers say the system will struggle to cope - and may well crash altogether - as institutions rush to join before the deadline on 31 January 2003.

Anxious university admissions officers say they haven't received full details of SEVIS' regulations. "It's going to be down to the wire," says John Pearson, director of the Bechtel International Center at Stanford University in California. He and others worry not just about breakdowns of the system leading to further delays for students, but about serious repercussions for universities that fail to meet SEVIS' requirements. Under current rules, such institutions could lose all international students, and proposed legislation could also strip them of federal research funding.

Muslim students who already have visas, meanwhile, are complaining of harassment upon their return to the United States from vacations. "This is having an impact on even the best science students' ability to focus on their work," says Altaf Husain, president of the Muslim Student Association of the US and Canada. "They are here working diligently, usually as a model student and citizen on campus, and then have to go through the humiliating experience" of an interrogation.

Back in May, John Marburger, President Bush's science adviser, proposed the creation of an Interagency Panel on Advanced Science Security to help to review visa applications. But according to Lerch, the proposal is in limbo pending the organization of the new Department of Homeland Security. 